\title{
Navigation Warfare (NAVWAR): Balancing the Position in Space between GPS and Galileo
}

\section{Navigációs hadviselés: egyensúlyozás a GPS és a Galileo-rendszerrel való helymeghatározás között}

In the concept of the Space Navigation Warfare (NAVWAR), balancing the position in space during the cold negotiations between the EU and the USA was the main aim in nullifying NAVWAR. Galileo, the new European navigational satellite system, will handle new potential operational fields and services, along with the existing U.S. navigational satellite system. However, the so-called U.S. NAVSTAR GPS system is operating in the same unified space, and it is currently the dominant and the standard navigational system in the world, therefore, it is considered a monopoly in this domain. Meanwhile, the Galileo system will share the GPS system in this single space, it will enhance both the performance and the accuracy, and it will also share its benefits with civilians. Furthermore, the Europeans will pursue the EU independency from the U.S. and the economic share as well. The objective of this article is to identify the justifications and rationale of both stakeholders, the EU and the U.S., in having their interests in space. Those interests started initially as two separated independent systems and ended up eventually after long negotiations as two competitive and intraoperative systems. Furthermore, the article will identify the positive technical efforts progress done by both sides in order to maintain the two systems competitive, modernised and dynamic to become one efficient system, similarly to the Internet worldwide. However, there will be less focus on other systems such as the Russian GLONASS system, the Chinese Beidou system, and other augmented systems for the reasons explained later in this article.

Keywords: Global Navigation Satellite System (GNSS), Ground Based Augmentation System (GBAS), Navigation Warfare (NAVWAR), Global Positioning System (GPS), Galileo

Eng., PhD Researcher, National University of Public Service (NUPS), Doctoral School of Military Engineering (DSME), e-mail: Ahmad_alhosban@yahoo.com, ORCID: https://orcid.org/0000-0001-7494-6067 
A navigációs műveletek (NAVWAR) koncepciójával kapcsolatos EU-USA egyeztetések során fö cél volt a navigációs műveletek hatásának kiküszöbölése. Ez egyaránt értendő az új európai Galileo müholdas navigációs rendszerre és a már hosszú ideje használt amerikai rendszerre. Az amerikai NAVSTAR GPS, ami ugyanabban az egységes müveleti térben üzemel, jelenleg a legelterjedtebb és standardnak tekintett navigációs rendszer, gyakorlatilag monopóliumnak tekinthetö. Eközben a Galileo, a potenciális új európai ürnavigációs rendszer ugyanabban a műveleti térben fog létezni, növeli a navigációs rendszerek teljesítményét és pontosságát a polgári alkalmazók részére, és elősegíti az EU függetlenségét és gazdasági növekedését. Ebben a cikkben bemutatom mindkét fél, az EU és az USA érvrendszerét azzal kapcsolatban, hogyan kezdődött a két, eredetileg független rendszer fejlesztése, és hogyan alakult ki ebből a két együttműködő, mégis versenyző rendszer. Továbbá, bemutatom azon pozitív erőfeszítések történetét, amely során mindkét fél fenntartotta a versenyképességét, és úgy modernizálta a rendszereit, hogy azok egységessé váljanak, az internethez hasonlóan. Kevesebb figyelmet fogok fordítani más rendszerekre, mint például az orosz GLONASS, a kínai Beidou, és más pontosságnövelö szolgáltatási rendszerek. Ennek okát a tanulmányban ki fogom fejteni.

Kulcsszavak: globális navigációs müholdrendszerek (GNSS), földi telepítésü kiegészítő rendszer (GBAS), navigációs műveletek (NAVWAR), globális helymeghatározó rendszer (GPS), Galileo

\section{Introduction}

In the satellite based navigational environment, the so-called Global Satellite Navigational Systems (GNSS) such as the American GPS, the Russian GLONASS, and the future European Galileo systems (also called constellations), the Signals in Space (SIS) are basically transmitted by the satellite vehicles in space, and then they are received by the ground receivers, after passing through the ionosphere and troposphere layers. Those Signals in Space (SIS) are intended to be used for many purposes, in both military and civilian domains, such as the communication relays with global coverage, the global navigational PVT: Position Velocity and Timing, surveillance, and the metrological uses. Most importantly, the navigational signals are used for the common grid and the common timing especially for military operations, from where the original idea of the GPS concept came. It was very important for the U.S. army to unify the grid of the strategical, operational and tactical missions worldwide as well as the timing for the deployed forces globally in many theatres using those space sensors. Moreover, the GPS system was invented in the early 1970 s and operated by the U.S. Air Force, Department of Defense DoD. Yet, its operation was shared with the Department of Transportation (DoT).

However, Russia, the other pole of the world at that time, would not be left behind, their idea of a Global Navigational Satellite System GLONASS was initiated and started to get operational in 1978, but using a different frequency band and different modulation scheme. Moreover, pursuing globalism was also their main hypothesis. Accordingly, the old continental Europe had its role also, the Europeans 
sought to have their independency in space. Therefore, their new born system, Galileo, was their hope and goal in sharing the space globally along with the U.S. and Russia. They started launching the first two satellites of the Galileo project, GIOVA A and $B$, at the end of 2005 after long debates and negotiations with the U.S. On the other hand, China launched their Beidou navigational system but it did not provide global coverage. It is only regionally focused over the Far East region [2].

Furthermore, the GPS satellites have got aged and deficiencies, Signals in Space (SIS) which came from the elder GPS Satellites are being received by the end-users without the required performance that meets the needs of both military and civilians; they are neither very accurate, nor being monitored. It was technically clear that the accuracy in position has suffered from many contributing errors such as the lonospheric and the multipath errors [1]. Moreover, the accuracy had deviated about 100 meters before the selectivity availability (SA) was switched off by the declaration of the American President Bill Clinton in May 2000. Thereby, the accuracy became around 10 meters, but this was also not accurate enough for all the applications. More importantly, the integrity factor of the SIS was not feasible; this may mislead or deceive the position information of the users without notifying them when the errors exceed the allowable limits of their tolerances.

Based on that, and due to such inaccurate and untrustable performance, the augmenting systems have been created over some regions by specific space agencies in order to compensate those drawbacks. Nevertheless, those augmentation systems are still using the same original GPS signals in a manner that they are corrected by the principles of the Differential GPS (DGPS). Those augmentations are classified into three main categories: the Space-Based Augmentation System (SBAS), the GroundBased Augmentation System (GBAS), and the Airborne-Based Augmentation System (ABAS). However, the SBAS main systems are more covering the wide regions than the other two types, such as the European EGNOS system, the Indian GAGAN system, the U.S. WAAS system and the Japanese MSAS system. These systems will not be discussed under the scope of this article due to their dependency on the same original GPS signal in space; in other words, they are considered the subsystems of the GPS system itself.

On the other hand, the Beidou Chinese system is only a regional GNSS system owned and operated by the People's Republic of China. Moreover, China is currently expanding the system to provide a global coverage using 35 satellites anticipated to be fully operational by the year 2021. Nevertheless, the Beidou system - previously called Compass - is still currently not a globally based system; therefore, it will not be dealt with under the scope of this article.

\section{The Technical and Political Status of GLONASS in the NAVWAR}

In order to examine the technical and the political status of the Russian GLONASS satellite system, the following questions are necessary to be answered: How can the GLONASS system be identified technically? What is its political status in the NAVWAR? 
A short history of the GLONASS system is highlighted to be able to answer the above two questions. First of all, it is well known that the GLONASS system had been launched during the cold war era since 1978, its name stands for (GLObal NAvigation Satellite System), and it is a radio-based satellite navigational system, which was initially developed for the use of the Soviet military. Moreover, it was classified as the second generation of satellite-based navigational system of the Soviets, and was intended to improve their first generation (Tsikada) system. Furthermore, the Tsikada system suffered deficiencies; it required one to two hours of signal processing to calculate the location with high accuracy. Moreover, the time of observing more than 4 satellites in the sky-view was limited, because it did not form a complete GNSS system at that time in spite of the fact that it was proposed to be fully operational by the year 2010, and to be compatible and interoperable with the GPS and the future Galileo systems.

Originally, the goal of developing the GLONASS system was to create more opportunities for the developers of the GNSS applications, allowing them to provide value-added services to the end-customers. Therefore, the development on the GLONASS system began in 1976, with a goal of a global coverage by 1991. Hence, numerous satellite launches had been completed since the year 1982, until the constellation of 26 satellites was obtained by the year 1995. Unfortunately, after its completion, the system rapidly fell into decay with the collapse of the Russian economy; therefore, the older satellites were taken out of service after their design lifetime expired without being replaced. In the end, only 8 satellites remained in the GLONASS orbits. Yet, and to change this situation, Russia decided to restore the system in major milestones that would end by the year 2011. Based on that, a federal program named "Global Navigation System" was undertaken by the Russian Government on 20 August 2001 with the Indian Government joining the program as a partner in both funding and services. Accordingly, both countries emphasised again the civilian side of the provided services, in particular the geodetic use of GLONASS. Later, on the $18^{\text {th }}$ of May 2007 , Russian President Vladimir Putin signed a decree providing open access to the civilian navigation signals of the GLONASS system to both Russian and foreign consumers free of charge and without limitations [2]. This was due to the competition with the charges and fees assumed by the Modernized GPS Block III and the potential Galileo at that time. However, this decree was considered another economic side of the global NAVWAR conducted by the Russian President.

Technically wise, the development and maintenance of the GLONASS system was conducted by the Federal Space Agency (FSA) (ROSCOSMOS, MOD). FSA had developed the second, and current generation of satellites called Uragan-M (also called GLONASS-M) in the beginning of 1990 and launched them for the first time in 2001. These satellites possess a substantially increased lifetime of 7 years and weigh slightly more (about 1,480 Kg). Furthermore, laser corner-cube reflectors were installed as aids for precise orbit determination and geodetic research. After that, 8 satellites were launched as of April 2007, and then an extra 14 satellites were launched by the year 2010. With that said, the total of 22 satellites of GLONASS-M was completed and fully operational. Next, the third generation satellites Uragan-K (GLONASS-K) started to be launched; they were designed with a lifetime of 10 to 
12 years, at a reduced weight of only $750 \mathrm{Kg}$, they offered an additional L-Band navigational signal, and entered service following the Uragan-M inventory depletion in 2008. Eventually, the fourth generation "GLONASS-KM" was decided to be in space, but unfortunately, this was not meant to be. It had been in the requirement definition phase since 2002 and proposed to be available by 2025 [2].

Politically wise, the United States and Russia initiated a cooperation in 2004, with the primary goal of enabling a civilian interoperability at the user level between both the GPS and Russia's GLONASS systems. Therefore, two working groups had been established to address two objectives: the first one was the radio frequency compatibility and interoperability for enhanced Positioning, Navigation, and Timing (PVT); and the other one was the technical interoperability between the Search-andRescue capabilities planned for the GPS and GLONASS systems. Nevertheless, all U.S.-Russia cooperation in this area was on hold status as of April 2014 [3].

In conclusion, the Russian GLONASS system is currently occupying the space along with the GPS system, but with no interference between their technical operations due to the fact that they are using different technologies and different frequencies, furthermore, they had been operated without any real cooperation between the U.S. and Russia since 2014.

\section{The Technical Differences between GPS and Galileo}

Assuming that there are differences and similarities between the two navigational systems, GPS and Galileo, a full technical and operational comparison is needed to be identified which would help to evaluate their strengths and weaknesses. Specifically, the GPS operational deficiencies from a European perspective and the extent to which level can Galileo intend to improve its performance in order to overcome those deficiencies. The main aspects of the comparison are the following:

Firstly, and in terms of purpose and sponsorship, the U.S. places priority on the security of the allied military capabilities when using GPS system, but the EU places priority of the Galileo system on the commercial viability for the civilians. In sponsorship wise, the GPS system was originally driven by the military's need for the increased weapon accuracy. Yet, the U.S. Government had established the Interagency GPS Executive Board (IGEB) since 1996. The IGEB manages senior-level policy for GPS and is chaired jointly by both the Department of Defense (DoD) and the Department of Transportation (DoT) whilst the U.S. Air Force is still operating the system. On the other hand, Galileo emerged as a joint system of the European Commission (EC) and the European Space Agency (ESA). Furthermore, the Galileo system is funded through a public-private partnership in which the EC and ESA provide funding in tandem with private companies participating in the project. In addition, the Galileo system will be operated by the so-called Galileo Operating Company (GOC) [4].

Secondly, and in terms of infrastructure, both the GPS and Galileo systems are subdivided into three parts: the space segment (also called satellite vehicles); the ground control segment (also called the command and control infrastructure); 
and the user segment (also called the end user or customer). The detailed comparison in this domain is as follows:

- The GPS space segment is comprised of 24 up to 30 satellites in a (Walker constellation) at an altitude of 10,898 nautical miles (roughly 20,200 Km), they are equally spaced in 6 orbital planes in right ascension around the earth, with an inclination of 55 degrees. The design of the GPS constellation guarantees that at least 5 satellites with good geometry are always seen in the sky-view to users worldwide in order to meet the accuracy requirements. Moreover, GPS currently uses two carrier signals, known as L1 (at $1575.42 \mathrm{MHz}$ ) and L2 (at $1227.6 \mathrm{MHz}$ ). Furthermore, GPS phases are historically as follow: Block I, Block II, Block IIA, and Block IIR (replenishment), Block IIF, IIR-M (for military uses on L5 separated), and finally the future modernised GPS Block III which is proposed to be fully operational in 2022 [3]. On the other hand, the proposed Galileo space segment will perform the space navigation mission with only minor differences; therefore, the Galileo system will employ more satellites in fewer orbital planes with a slightly higher altitude and inclination. Literally, the Galileo system will consist of up to 30 satellites in a Walker constellation at an altitude of $23,616 \mathrm{Km}$, they are equally spaced within three orbital planes with a 56-degree inclination. Furthermore, it plans to employ the following signals: two signals on the E5A band centred at $1176.45 \mathrm{MHz}$, two signals on E5B band at $1207.14 \mathrm{MHz}$, three signals on E6 band at $1278.75 \mathrm{MHz}$, and three signals on E2-L1-E1 band at $1575.42 \mathrm{MHz}$ (see Figure 1). Hence, the Galileo satellites are physically smaller, lighter and more covering the world than the GPS ones [5], [6].

- The ground control segments of the two systems are very similar in operation, infrastructure and the way they are controlling the space segments to maintain them operational and healthy.

- Concerning the end-user segment (or the customer receivers), the U.S DoD initially developed the GPS system to support national security. The U.S. armed forces are still the primary intended customers for the GPS system for the Precise Positioning Service (PPS) with higher accuracy (less than $15 \mathrm{ft}$.), but the other users of the rest of the world are using the Standard Positioning Service (SPS) with less accuracy (10-20 m), especially after President Clinton's declaration to turn off the Selective Availability (SA) in May 2000, before the SA turning off, the accuracy was around $100 \mathrm{~m}$. On the other hand, the EU marketed Galileo as a public GNSS dedicated to the civilian and the commercial users, and reduced Galileo's military utility. Furthermore, the Galileo provided services are more accurate and more precise than the current given services by the GPS system. 


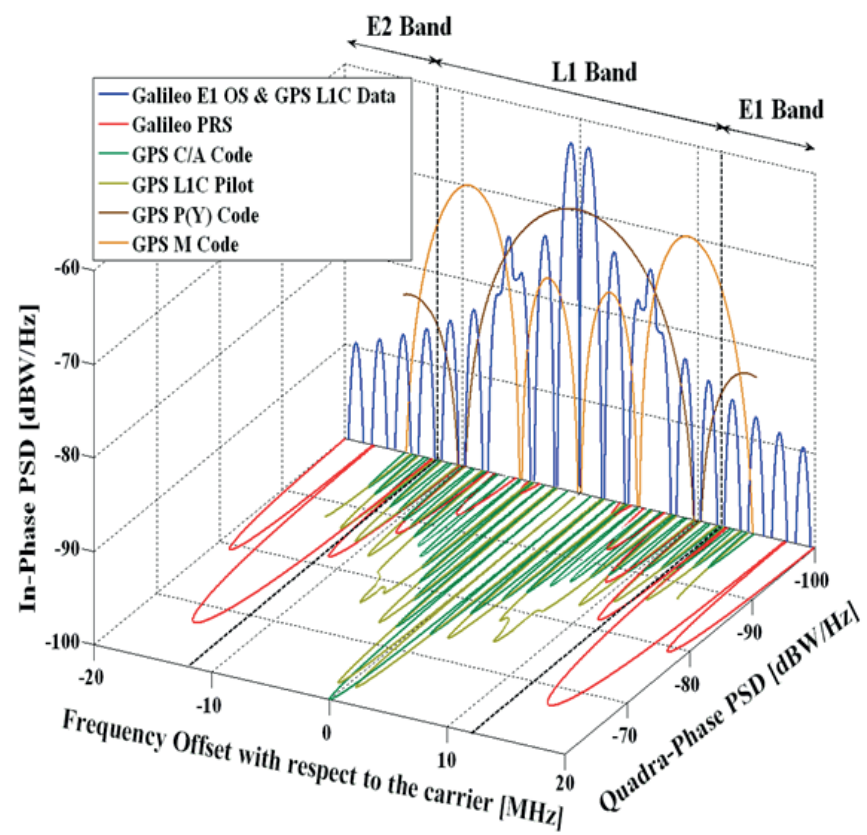

Figure 1.

New Modern GNSS signal structure [2]

Thirdly, and in terms of services, there are differences between the two systems, especially the services of the Galileo system, and in specific their potential effects on the GPS system. In short, the GPS system provides the Position, Navigation, and Timing (PNT) services with two different levels of accuracy: The Standard Positioning Service (SPS) level and the Precise Positioning Service (PPS) level. The unencrypted SPS offers PNT services free of charge to all users without any alerts to users when being out of their tolerances' limits, while the PPS is dedicated for military purposes only. In contrast to GPS, Galileo plans to offer five types of services: The Open Service (OS), the Commercial Service (CS), Safety-of-Life (SoL) Service, the Public Regulated Service (PRS), and the Search and Rescue (SAR) Support Service. All of them guarantee alerts to users but not free of charge (with the exception of the Open Service [OS], which will be free). Saying that, both GPS and Galileo systems provide the basic PNT (Positioning, Navigation and Timing) services open to all users as well as the augmented services restricted to authorised users. Nevertheless, Galileo plans to offer additional features such as: the service guarantees, the global-integrity monitoring, and the additional data services supporting commercial markets; doing this for the sake of an attempt to overcome the GPS limitations from a civilian perspective.

Fourthly and lastly, in terms of limitations and vulnerabilities, both systems are identified to be vulnerable to jamming and Electronic Attacks (EA) because they are both using the electromagnetic energy in their SIS; this limitation may prevent using them in some critical applications such as the final phase of landing of an aircraft on a runway, or in other military precise missions that need weapons' high accuracy and 
sustainability of the used SIS. However, Galileo experimental trials showed more immune signal structure to jamming than GPS. This immunity is due to the fact of using the Binary offset Carrier (BoC) modulation scheme, and due to higher transmitted power that can mitigate high power jammers. Nevertheless, the proposed GPS Block III promises an enhanced performance as good as Galileo in this domain [9].

The above comparison evaluates both systems, and sheds light on how the Galileo system will be competitive to the GPS system especially in terms of the civilian services and their proposed quality. That means the initiatives of Galileo from the European perspective are highly justified and touch the top of the competitiveness as well as Galileo worthiness to share the space with the other navigational systems in the concept of NAVWAR. The following sections of this article show those initiatives and justifications.

\section{Why Galileo Initiatives?}

The intention of the European Union (EU) and the European Space Agency (ESA) is to establish the Galileo system. However, some questions and assumptions need to be answered in this domain: Why is Europe pursuing the development of Galileo while a free to all global space-based radio navigation system already exists? Despite the high costs of developing and deploying its own redundant system, Europe is pressing ahead. Does GPS have deficiencies that Galileo will fix or improve? Are there any motives that have not yet been made public [4: 2]?

In order to answer the above questions, Europe's rationale to build a separate satellite navigation system was identified as follows: improved performance, independence from the United States, and economic opportunity.

Firstly, and in terms of the improved performance, the Europeans' basic assumption was that the GPS system may not be upgraded to meet the future needs; their debates were that the enhanced GPS B-III was planned to begin launching in 2012 [4], but unfortunately, it is currently anticipated to be launched in 2022 or may be beyond [3]. Hence, the GPS current performance in the form of accuracy, reliability and vulnerability became a primary concern and a strong motive for the European development of Galileo. Furthermore, the GPS accuracy still degrades at high latitudes and in urban areas; the five-meter accuracy of GPS is available only $17 \%$ of the time, also the GPS civilian service (SPS) cannot be guaranteed worldwide all the times. For example, in 2000, GPS satellite malfunctions deprived the areas of Oklahoma, Kansas and Nebraska from navigational signals for 18 minutes. Consequently, if the satellite navigation is considered a keystone of transportation infrastructure, then even minor service discontinuities would cause severe consequences on the safety of people and assets. Based on that, Galileo is foreseen to be the promising global navigational satellite system, which will overcome all these deficiencies and GPS Block III will also overcome most of them and free of charge to the users.

Furthermore, and in terms of GNSS importance, it has obviously been noted that no single NATO mission had been performed without using the current GPS systems; it is being used in every single air force, land and Maritime's missions. Therefore, the GPS system has been the essence and the core of many operational needs since its announcement 
date, such as: the digital mapping, the unified timing and the common synchronisations especially in the deployable operations. Furthermore, and from a military perspective, signal officers on duty whilst the planning phase of operation should investigate the applicable technologies and the possible technical devices in order to give the needed suggestions for the implementation. Moreover, the digital soldier must nowadays be the best-equipped soldier of the battlefield who is connected to the theatre of war/ operations with all it is needed of the latest technologies such as computers, wireless communication and by using GPS receivers. Therefore, the personal communication system should provide the ability to perform all the tasks with the appropriate support such as the digital GPS maps, the picture and voice commands and the messaging options [8]. Hence, it is important in place, that the EU operational decision-makers to seek for the optimal best technologies that meet their missions accomplished precisely and successfully, depending on their own secure timing and synchronisation of the potential Galileo system.

However, it was definitely clear for the EU that they can successfully proceed in their own Research and Development R\&D efforts. Moreover, and according to NATO and EU, a newly owned GNSS system with an improved technical performance higher than the given GPS SPS services by USA to NATO allies in joint Operations, is strongly needed.

Secondly, and in terms of the independence from the United States, the rationale behind it was identified as follows:

- The political independence: Europe plans to employ a GNSS to aid the implementation of a broad set of policies that includes regulating agriculture, fisheries and transportation services. Therefore, without Galileo, European critical infrastructure will rely on a system owned and operated by a foreign military power. However, the United States concluded that this idea was not in its best interest. Nevertheless, the final negotiations with the U.S. showed their conditioned approval, especially after China's involvement in funding the Galileo project, in a way that would not affect the interest of U.S. interests. Yet, China's involvement was used by the EU as a pushing card towards the final approval.

- The security independence: The European security perspective has changed over the past years. Therefore, Galileo will play an important role in the future defence of the EU. Historically, Europe has depended on the United States for security since the end of World War II. Yet, the EU security was faded by America's reluctance to prosecute the war in Kosovo, as the American priority changed in the absence of the USSR. Furthermore, it was certainly noted that the post-9/11 environment refocused America's priorities on homeland defence and the war on terrorism. Hence, Europe insists that the Galileo system is designed specifically for the civilian purposes - as compared to GPS, which was designed during the Cold War for military purposes only. Consequently, the EU implies that Galileo will be the best choice for security of the European civilians, due to the fact that: meeting civilian needs is not the Pentagon's top priority any more.

- The technological independence: It has been approved that Galileo is not the first European venture designed to overcome the technological dominance of the U.S. For example, the Europeans independently pursued the development 
of the Ariane launch booster against the U.S. Delta, the Airbus against the Boing aircraft, and the land communications Ericsson switches against the U.S. ones, all of these are good examples of the EU's ability of competition. Therefore, the U.S. dominance in satellite navigation technology once again threatens Europe in the technological dependence.

Table 1.

European rationale summary [Compiled by the author.]

\begin{tabular}{|c|c|c|}
\hline Improved performance & Independence from the U.S. & Economic opportunity \\
\hline $\begin{array}{l}\text { The GPS performance of } \\
\text { accuracy, reliability, and } \\
\text { vulnerability has become } \\
\text { a primary concern and motive } \\
\text { for the European development } \\
\text { of Galileo. } \\
\text { GPS five-meter accuracy was } \\
\text { available only } 17 \% \text { of the time. } \\
\text { The GPS civilian service, } \\
\text { the SPS is not guaranteed } \\
\text { worldwide at all times. } \\
\text { Even GPS Block III will } \\
\text { overcome most of such } \\
\text { deficiencies and free of charge } \\
\text { to the civilian users; it was } \\
\text { planned to be launched by } \\
2012 \text {, delayed to } 2018 \text {, and } \\
\text { then started in } 2019 \text {, only } 2 \\
\text { out of the } 10 \text { satellites were } \\
\text { launched, the second on } 25 \\
\text { August } 2019 \text { [10]. }\end{array}$ & $\begin{array}{l}\text { Political independence } \\
\text { Europe plans to } \\
\text { employ a GNSS to aid } \\
\text { the implementation of a broad } \\
\text { set of policies that includes } \\
\text { infrastructure, regulating } \\
\text { agriculture and transportation } \\
\text { services, which cannot be } \\
\text { relied on a system owned by } \\
\text { foreign military power. } \\
\text { Security independence } \\
\text { Europe's security was faded, } \\
\text { as an American priority in } \\
\text { the absence of the USSR } \\
\text { emerged, by America's } \\
\text { reluctance to prosecute } \\
\text { the war in Kosovo. } \\
\text { The post-9/11 environment } \\
\text { refocused American priorities } \\
\text { on homeland defence and } \\
\text { the war on terrorism. } \\
\text { EU implies that Galileo is } \\
\text { the best choice for the security } \\
\text { of the civilians because civilian } \\
\text { needs is not the Pentagon's } \\
\text { top priority any more. } \\
\text { Technical independence } \\
\text { Galileo is not the first } \\
\text { European venture designed to } \\
\text { overcome U.S. technological } \\
\text { dominance. } \\
\text { Europeans independently } \\
\text { pursued the development of } \\
\text { the Ariane launch booster, } \\
\text { Airbus against Boing aircraft } \\
\text { and land communications } \\
\text { Ericsson switches, just to } \\
\text { mention a few examples of } \\
\text { the EU's ability of competition. }\end{array}$ & $\begin{array}{l}\text { Market share } \\
\text { Sales of the Galileo receivers } \\
\text { are expected to increase } \\
\text { from } € 100 \text { million in } 2010 \\
\text { to about } € 875 \text { million by } \\
2020 \text {, representing market } \\
\text { penetration rising from } 13 \% \text { up } \\
\text { to } 52 \% \text {. } \\
\text { Creating jobs } \\
\text { Ranging from } 100,000 \text { jobs by } \\
2020 \text { to } 146,000 \text { by } 2025 \text {. } \\
\text { Royalties and service charges } \\
\text { Galileo will gain more and } \\
\text { more profits through royalties } \\
\text { and service charges. }\end{array}$ \\
\hline
\end{tabular}


Thirdly, and in terms of the EU economic opportunity share in the worldwide market, it was anticipated that if the EU will establish a foothold in space racing, then the sales of the Galileo receivers are expected to increase from $€ 100$ million in 2010 to about $€ 875$ million by 2020 or even more and this represents market penetration rising from $13 \%$ up to more than $52 \%$. It will also drive the creation of jobs ranging from 100,000 jobs by 2020 to about 146,000 by the year 2025. In addition to driving up market share and creating jobs, Galileo will gain more and more profits through royalties and service charges [4].

In conclusion, with Galileo, Europe does not only secure a degree of political, security and technological independence from the United States, but also, it will provide Europe with an economic window of opportunity to seize the satellite navigation market away from the United States market dominance and to set a new global standard [4: 45]. Table 1 summarises all the mentioned rationale and justifications.

\section{Galileo Implications}

In order to examine the implications of the Galileo system, the following two questions are needed to be answered: What are the implications of the proposed Galileo system for the United States? How should the United States respond?

Basically, the national security and economic concerns generated by the emergence of Galileo reviewed the U.S. policy towards Galileo and provided recommendations for the future. The Galileo system has attracted the interests and the investments from many non-European nations, including the People's Republic of China since its announcement date. This reflects the fact that Galileo is a fast-becoming technology that gets into reality rapidly. Although its Initial Operation Capability (IOC) has recently started, its Final Operation Capability (FOC) has not started yet; the FOC has delayed since the announcement of its estimated time due to some financial constraints in the EU economic share.

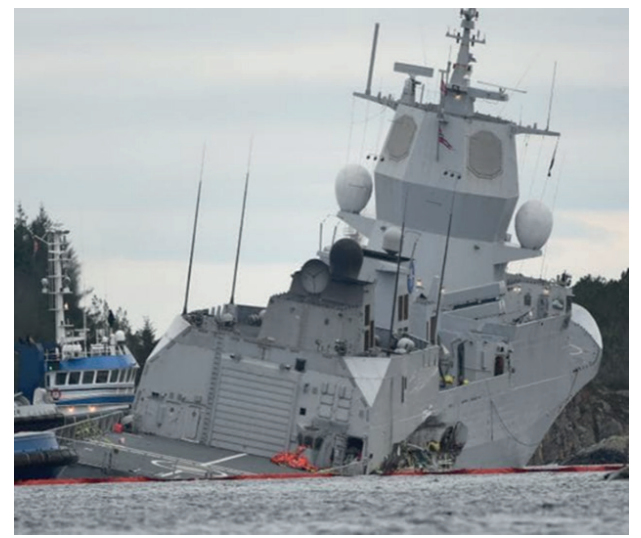

Figure 2.

Collision of the Norwegian frigate "KNM Helge Ingstad" AFP [7] 
In terms of implications, the EU has claimed some technical issues in the performance of the GPS system in order to succeed in nullifying the NAVWAR concept born since 1996. One of those technical issues was the voluntary of the GPS system to jamming. The EU claimed that not only the civilian L1 frequency is vulnerable to jamming, but also the military $L 2$ frequency, because the $L 2$ is basically using the $L 1$ frequency in the acquisition process to calculate the position in the PPS service. Saying that means that both the military and the civilian users would be at a risk especially when they are jammed by the adversary within the operation theatre. The U.S. security would also be risked. On the other hand, Galileo will not face those issues as designed. One example for this technical issue has recently and clearly appeared in the huge NATO Exercise called "Trident Juncture" in 2018; the Norwegian frigate "KNM Helge Ingstad" suffered a navigation failure leading to a collision with the tanker "Sola TS" on the $8^{\text {th }}$ of November 2018 in the Hjeltefjord near Bergen, as seen in Figure 2. This exercise involved about 50,000 personnel, tens of thousands of vehicles, and dozens of ships and aircraft. All participants were forced to practice their skills in and around Norway in the freezing waters and the icy mountains. The exercise was labelled as the Alliance's largest exercise since the Cold War, with a total of 29 NATO members plus the non-NATO members Finland and Sweden. Actually, the GPS signals that were guiding the ships, the aircraft (both civilian and military), the tanks, the trucks and the troops started to fail. Nevertheless, the U.S. forces declared less damage. It was most likely due to their using of the PPS service that had higher accuracy and was more immune to jamming compared with other forces who were using the SPS service only [7].

Moreover, the other main technical issue concerning Galileo is that the U.S. started to design GPS BLOCK IIIF-M military code, with a higher power on a separated L5 frequency. Meanwhile, the International Telecommunications Union (ITU) had authorised Galileo to transmit its PRS and OS signals in the same frequency range as the GPS M-code, because the Europeans intended to plan transmitting the PRS signal using the same modulation scheme as the GPS M-code, and directly overlaying Galileo's PRS signal on top of the GPS M-code signal so that to interfere with GPS signals. Therefore, any attempt by the United States to jam the PRS would also jam their M-code signal. This means effectively nullifying the NAVWAR with the U.S. GPS system. With that done, neither the monopoly of the U.S. concept in space navigation would be valid anymore, nor its superiority in space control.

In response, a third technical issue was raised as well. NATO highlighted concerns regarding the integrity of the Galileo PRS encryption regime, fearing that the PRS signals could be compromised and exploited by any adversary. Likewise, the United States feared that rogue states, terrorists, or even states acting against the U.S. interests could use the Galileo PRS to their advantage. Nevertheless, the EU asserted the expertise to design and implement an effective governmental encryption. Taking into consideration that the resulting technology could be made available only to the European authorities who are controlling the Galileo PRS signal and the U.S. should trust the EU regarding this issue. In this manner, Galileo would mitigate fears of the PRS encryption. By saying and proving that, the EU could face challenges implementing Galileo, but the U.S. would not make this happen, at least initially. 
Nevertheless, things have currently been changed, interoperability and cooperation do exist in both systems.

From the U.S. perspective, the history of negotiations is summarised as follows:

- Initially, the U.S. policy employed a "wait-and-see" approach towards Galileo, downplaying the need for another system and doubting Europe's ability to pull it off.

- Officially, the United States saw "no compelling need for Galileo" because the GPS system would continue to meet the needs of users worldwide; there was a tendency in the U.S. planning to confuse the unfamiliar with the improbable.

- In February 1999, the EU announced the plans to pursue an independent system, and they obtained the approval and the funding to launch the Galileo program starting from 2002.

- In May 2000, the United States stopped degrading the GPS civilian accuracy by turning off the Selective Availability (SA) in an effort to make the GPS system more responsive to the civilian and the commercial users worldwide.

- In September 2000, the U.S. accelerated the GPS modernisation phase by upgrading 12 out of the 20 Block IIR satellites, and included an additional civilian signal (L2C) and other two military signals (M-code), that were one of the root causes of the famous crisis of the U.S. economy at that time.

- Once the United States accepted that, the EU would build the Galileo system, whether the U.S. liked it or not, the policy was softened from blocking Galileo's progress to ensuring its compatibility and interoperability with the GPS system, similarly to the internet network.

- Lately, the United States recommended a specific signal structure to be shared by Galileo's OS and GPS B-III.

- In February 2004, the EU positively responded to the U.S. offer, and was potentially removing the last major obstacle.

Finally, and as per published by the EU Publication website in 2014, the U.S.EU Agreement on GPS-Galileo cooperation was signed in 2004, and it had laid down the principles for the cooperation activities between the United States of America and the European Union in the field of satellite navigation. That agreement resolved all the technical, trade and security issues. Therefore, it eventually nullified the NAVWAR between both of them.

\section{Conclusions}

In conclusion, the proposed Galileo satellite navigation system challenges the U.S. national security and economic productivity. The European system currently threatens the U.S. space superiority because it could interfere with GPS signals and nullify the concept of NAVWAR. However, the questionable security of the Galileo PRS encryption scheme and broad international participation heighten the fear of the future hostile use of Galileo against the U.S. interests. Economically, Galileo erodes GPS's status as the world standard. The EU's need to generate revenue 
raises concerns regarding access to the signal specifications, the fair-trade practices and the proliferation of space technology. In response, the United States should work with the EU to develop a common standard for the satellite navigation as a framework of cooperation and competition similarly to the Internet worldwide. Within this framework, the United States must strengthen GPS's competitiveness by two actions; the first is the accelerating of the GPS modernisation phase wherever possible to minimise Galileo's appeal, and the second is the separating of the military and the civilian services in order to enable both sectors to minimise conflict within a dual use system and focus on their own specific needs. In this manner, the United States can reach to the extent of: cooperating where it can be done, and competing where it must be done, in order to maintain a global leadership status in the satellite navigation and uphold its position in space [4].

\section{References}

[1] I. Sayim, H. Lang and D. Zhang, "Ionospheric delay prediction and code-carrier divergence testing for GBAS using neural network and GPS L1," Aerospace Science and Technology, vol. 70, pp. 66-75, 2017. DOI: https://doi.org/10.1016/j. ast.2017.07.039

[2] B. Eissfeller, V. Kropp, G. Ameres and D. Sanroma, „Performance of GPS, GLONASS and Galileo," 2007, pp. 185-199. [Online]. Available: www.researchgate.net/ publication/237639244_Performance_of_GPS_GLONASS_and_Galileo [Accessed: 10 Oct. 2019]

[3] Official U.S. government information about the Global Positioning System (GPS) and related topics, "International Cooperation," Official U.S. government information about the Global Positioning System (GPS) and related topics, [Online]. Available: www.gps.gov/policy/cooperation/\#russia [Accessed: 21 Nov. 2019]

[4] S. W. Beidleman, "GPS versus Galileo: Balancing for Position in Space," USAF CADRE Paper No. 23, Air University Press Maxwell Air Force Base, Alabama, USA, 2006. DOI: https://doi.org/10.21236/ADA453360

[5] European Space Agency, ESA, "Galileo Future and Evolutions," European Space Agency, ESA, 18 Oct. 2018. [Online]. Available: https://gssc.esa.int/navipedia/ index.php/Galileo_Future_and_Evolutions [Accessed: 19 Nov. 2019]

[6] European Space Agency, ESA, "Contract signing to boost performance and security of Galileo services," European Space Agency, ESA, 18 Oct. 2018. [Online]. Available: www.esa.int/Our_Activities/Navigation/Contract_signing_to_boost_ performance_and_security_of_Galileo_services [Accessed: 19 Nov. 2019]

[7] J. Seidel, "GPS signals jammed: Norway, Finland warn pilots Russia may blind their navigation systems," news.com.au, 14 Nov 2018. [Online]. Available: www.news.com. au/technology/innovation/military/gps-signals-jammed-norway-finland-warnpilots-russia-may-blind-their-navigation-systems/news-story/ee28be793012e9b 9e66d59ffba439242 [Accessed: 21 Nov. 2019] 
Ahmad Alhosban: Navigation Warfare (NAVWAR): Balancing the Position in Space...

[8] T. Farkas and E. Hronyecz, "Info-Communication System Requirements for Deployable Rapid Diagnostic Laboratory Support," AARMS, vol. 14, no.1. pp. 53-61, 2015.

[9] A. Alhosban, "Electronic Warfare in NAVWAR: Impact of Electronic Attacks on GNSS / GBAS Approach Service Types C and D Landing systems and their proposed Electronic Protection Measures (EPM)," Hadmérnök, vol. 14, no. 2, pp. 238-255, 2019.

[10] „US Air Force website," [Online]. Available: www.losangeles.af.mil/News/ArticleDisplay/Article/1941274/smc-and-its-government-industry-partners-successfullylaunch-gps-iii-sv-2-satel/ [Accessed: 17 Oct. 2019] 